\title{
Perbandingan Postoperative Cognitive Dysfunction (POCD) Fase Akut Pasca Joint Arthroplasty pada Pasien Usia Lanjut Antara Anestesi Umum dan Anestesi Epidural
}

\author{
Syahpikal Sahana, Iwan Abdul Rachman, Dewi Yulianti Bisri \\ Departemen Anestesiologi dan Terapi Intensif \\ Fakultas Kedokteran Universitas Padjadjaran/RSUP Dr. Hasan Sadikin Bandung
}

\begin{abstract}
Abstrak
Usia lanjut merupakan faktor risiko terjadinya postoperative cognitive dysfunction (POCD). Pemilihan teknik anestesi yang tepat pada usia lanjut akan menurunkan risiko kejadian POCD. Penelitian ini bertujuan untuk membandingkan angka kejadian POCD pada pasien usia lanjut yang menjalani operasi joint arthroplasty antara anestesi umum dan anestesi epidural. Penelitian berlangsung pada bulan Juli-Oktober 2019 di RSUP Dr. Hasan Sadikin Bandung. Penelitian dilakukan menggunakan metode randomized control trial dengan melibatkan 48 pasien yang menjalani tindakan joint arthroplasty. Subjek penelitian dibagi menjadi kelompok anestesi umum (GA) dan anestesi epidural (EA) menggunakan bilangan acak. Penilaian status mental pasien dilakukan menggunakan Mini mental state examination (MMSE) pada saat preoperasi dan tujuh hari pascaoperasi. Perbandingan proporsi kajadian POCD pada kedua kelompok dianalisis dengan menggunakan uji chi-square. Kejadian POCD pada kelompok GA $(37,5 \%)$ lebih tinggi dari kelompok EA $(8,3 \%)$ dan secara statistik perbedaan proporsi kejadian POCD pada kedua kelompok bermakna signifikan $\mathrm{p}=0,016(\mathrm{p}<0,05)$. Simpulan penelitian bahwa kejadian postoperative cognitive dysfunction (POCD) pada pasien usia lanjut yang menjalani joint arthroplasty dengan anestesi epidural lebih kecil dibanding dengan anestesi umum.
\end{abstract}

Kata kunci: Anestesi epidural, anestesi umum, joint arthroplasty, mini mental state examination, postoperative cognitive dysfunction

\section{Comparison of General Anesthesia on Postoperative Cognitive Dysfunction (POCD) in Joint Arthroplasty with Epidural Anesthesia in Elderly Patients}

\begin{abstract}
Old age is a risk factor for postoperative cognitive dysfunction (POCD). Elder people often have to undergo many surgeries, one of which is joint arthroplasty surgery. Selecting appropriate anesthetic techniques for elderly patients to reduce POCD is always controversial. The study aimedto compare the POCD incidence in elderly patients who underwent joint arthroplasty surgery using the general anesthesia and epidural anesthesia. The study was conducted in July-October 2019 at the RSUP Dr. Hasan Sadikin Bandung. This study used a randomized control trial method involving 48 elderly patients who underwent joint arthroplasty using randomized control trial method. Research subjects were divided into the General Anesthesia group (GA) and the Epidural Anesthesia group (EA) using random numbers. Both groups mental status was assessed using the mini mental state examination (MMSE) during preoperative and seven days postoperatively. A comparison of the proportion of POCD incidence in the two groups were analyzed using the chi-square test. The result showed that the proportion of POCD incidence in the GA group (37.5\%) was higher than the EA group (8.3\%), and the difference was statistically significant $p=0.016(p<0.05)$. The study concludes that epidural anesthesia in the joint arthroplasty procedure of elderly patients is superior vs. general anesthesia.
\end{abstract}

Keywords: Epidural anesthesia, general anesthesia, joint arthroplasty, mini-mental state examination, postoperative cognitive dysfunction

Korespondensi: dr. Syahpikal Sahana, Departemen Anestesiologi dan Terapi Intensif Fakultas kedokteran Universitas Padjadjaran/Rumah Sakit Dr. Hasan Sadikin Bandung, Jl. Pasteur No. 38 Bandung 40161, Tlpn 022-2038285, Email syahpikalsahana@gmail.com 


\section{Pendahuluan}

Postoperative cognitive dysfunction (POCD) merupakan penurunan fungsi kognitif yang sering ditemukan pada pasien yang menjalani operasi mayor. Secara umum, insidensi kejadian POCD hari ketujuh pada operasi mayor selain operasi jantung adalah 25,8\%. Pada penelitian lain insidensi POCD ditemukan 21,2\% setelah anestesi umum dan $12,7 \%$ pada anestesi regional. Usia lanjut merupakan faktor risiko yang sangat berperan terhadap kejadian POCD dengan insidensi $41,4 \%$ pada usia lebih dari 60 tahun. Kejadian POCD pada tujuh hari pascaoperasi (fase akut) berhubungan dengan peningkatan morbiditas dan mortalitas pasien pada tahun pertama pascaoperasi. Kecendrungan seseorang mengalami POCD seringkali dikaitkan dengan konsep cerebral cognitive reserve. Teori ini menjelaskan tentang kemampuan seseorang bertahan terhadap paparan obat anestesi dan tindakan operasi dibandingkan dengan orang lain yang mendapat paparan sama. ${ }^{1-3}$

Tindakan operasi joint arthroplasty sering dilakukan pada pasien usia tua yang bertujuan meningkatkan kualitas hidup dengan memperbaiki kemampuan mobilisasi pasien. Teknik anestesi yang sering dilakukan pada operasi ini adalah anestesi umum (GA) dan anestesi epidural(EA).POCDakan menurunkan kualitas hidup pasien pascaoperasi sehingga diperlukan penelitian yang membandingkan kejadian POCD antara kedua teknik anestesi untuk memilih teknik anestesi dengan risiko POCD yang lebih kecil. ${ }^{4,5}$

Beberapa penelitian mencoba membandingkan kejadian POCD pada tindakan operasi hip arthroplasty antara GA dan EA. Dari 50 pasien yang dilakukan GA diperoleh 18 pasien mengalami POCD, sedangkan pada 50 pasien dengan EA terdapat 8 pasien yang mengalami POCD. Kejadian POCD pada GA lebih banyak dan bermakana dibanding dengan EA. Pemerikasaan protein penanda kerusakan neuron yaitu protein Tau pada GA juga ditemukan lebih tinggi dibanding dengan kelompok EA.5,6 Tujuan penelitian ini adalah mengetahui perbandingan angka kejadian
POCD fase akut pada pasien usia lanjut yang menjalani operasi joint arthroplasty antara GA dan EA.

\section{Subjek dan Metode}

Penelitian ini menggunakan metode eksperimental analitik komparatif kategorik dengan design single blind randomized controlled trial. Subjek penelitian adalah pasien yang menjalani operasi elektif joint arthroplasty mulai bulan Juli 2019 sampai jumlah sampel terpenuhi di RSUP Dr. Hasan Sadikin (RSHS) Bandung. Pemilihan subjek penelitian berdasarkan kriteria inklusi, yaitu pasien usia pasien $>60$ tahun, status fisik American Society of Anesthesiologists (ASA) kategori II-III, skor mini mental state examination (MMSE) >23 (normal), dan bersedia mengikuti penelitian dan mengisi informed consent. Kriteria eksklusi adalah pasien buta huruf, tidak mengerti bahasa Indonesia, mengalami angguan penglihatan, pendengaran, dan memiliki alergi terhadap obat yang digunakan pada penelitian. Kriteria pengeluaran adalah pasien tidak dapat dinilai MMSE pada hari ke-7 pascaoperasi, perubahan mean arterial pressure (MAP) $<60 \%$ dibanding baseline selama operasi, waktu operasi $>4$ jam, mendapat tranfusi darah $>2$ labu, mengalami desaturasi $<80 \%$ yang tidak dapat diatasi $>2$ menit dan pasien delirium pada hari ke-7.

Penentuan jumlah sampel menggunakan formula perhitungan besar sampel pada penelitian analitik komparatif kategorik tidak berpasangan dan didapatkan jumlah sampel minimal 24 pasien untuk masing-masing kelompok. Pengambilan sampel dilakukan secara consecutive sampling dan dilakukan randomisasi subjek ke dalam dua kelompok penelitian. Subjek penelitian dibagi menjadi dua kelompok yaitu kelompok GA mendapat perlakuan tindakan anestesi umum dan kelompok EA mendapat perlakuan anestesi epidural. Alokasi subjek ke dalam kelompok dilakukan dengan metode randomisasi sederhana menggunakan tabel bilangan acak. Penelitian dilakukan di RSUP Dr. Hasan Sadikin Bandung, pada bulan Juli-Oktober 2019 
Tabel 1 Karakteristik Subjek Penelitian

\begin{tabular}{|c|c|c|c|}
\hline \multirow[b]{2}{*}{ Variabel } & \multicolumn{2}{|c|}{ Tindakan Anestesi } & \multirow[b]{2}{*}{ Nilai $p$} \\
\hline & $\begin{array}{l}\text { Anestesi Umum } \\
(n=24)\end{array}$ & $\begin{array}{l}\text { Anestesi Epidural } \\
(\mathrm{n}=24)\end{array}$ & \\
\hline \multicolumn{4}{|l|}{ Usia (tahun) } \\
\hline Mean \pm SD & $70,96 \pm 8,57$ & $72,88 \pm 9,35$ & 0,105 \\
\hline \multicolumn{4}{|l|}{ Pendidikan } \\
\hline SD & 4 & 5 & 0,137 \\
\hline SMP & 7 & 8 & \\
\hline SMA & 5 & 5 & \\
\hline$>$ SMA & 8 & 6 & \\
\hline Indeks massa tubuh $\left(\mathrm{kg} / \mathrm{m}^{2}\right)$ & & & 0,409 \\
\hline $18,5-24,9$ & 20 & 19 & \\
\hline $25,0-29,9$ & 4 & 5 & \\
\hline Status fisik ASA & & & 0,130 \\
\hline 2 & 11 & 13 & \\
\hline 3 & 13 & 11 & \\
\hline
\end{tabular}

Keterangan: Data numerik nilai p diuji dengan uji t atau uji mann-whitney bila distribusi data tidak normal. Data nominal nilai $\mathrm{p}$ dihitung berdasarkan uji chi-square. Nilai kemaknaan berdasarkan $\mathrm{p}<0,05$.

setelah mendapat persetujuan dari Komite Etik Penelitian Kesehatan Fakultas Kedokteran Universitas Padjdjaran/RSUP Dr. Hasan Sadikin Nomor LB.02.01/X.2.2.1/11913/2019.

Prosedur penelitian dimulai inform consent mengenai tindakan anestesi dan penelitian yang dilakukan. Pasien yang sesuai kriteria inklusi dan mananda tangani informed consent dijadikan sebagai subjek penelitian. Pemeriksaan awal fungsi kognitif dengan tes MMSE dilakukan sebelum tindakan anestesi. Semua subjek dilakukan tindakan

Tabel 2 Monitoring Intraoperasi

\begin{tabular}{lccc}
\hline \multirow{2}{*}{ Variabel } & \multicolumn{2}{c}{ Tindakan Anestesi } & \\
\cline { 2 - 3 } & $\begin{array}{c}\text { Anestesi Umum } \\
(\mathbf{n = 2 4 )}\end{array}$ & $\begin{array}{c}\text { Anestesi Epidural } \\
\mathbf{( n = 2 4 )}\end{array}$ & Nilai p \\
\hline $\begin{array}{l}\text { Lama operasi (menit) } \\
\text { Mean } \pm \text { SD }\end{array}$ & $120,0 \pm 12,1$ & $116,3 \pm 11,8$ & 0,765 \\
$\begin{array}{l}\text { Lama anestesi (menit) } \\
\text { Mean } \pm \text { SD }\end{array}$ & $126,9 \pm 13,3$ & $124,6 \pm 12,8$ & 0,668 \\
$\begin{array}{l}\text { Tekanan rerata arteri (mmHg) } \\
\text { Mean } \pm S D\end{array}$ & $91,6 \pm 6,2$ & $93,5 \pm 7,4$ & 0,317 \\
$\begin{array}{l}\mathrm{SpO}_{2(\%)} \\
\text { Mean } \pm S D\end{array}$ & $99,2 \pm 0,4$ & $99,2 \pm 0,3$ & 0,261 \\
\hline
\end{tabular}

Keterangan: Data dilakukan uji t pada data dengan distribusi normal dan Mann Whitney bila tidak memenuhi asumsi uji t. Nilai kemaknaan berdasarkan nilai $\mathrm{p}<0,05$. Tanda* menunjukkan nilai $\mathrm{p}<0,05$ artinya signifkan atau bermakna secara statistik. 


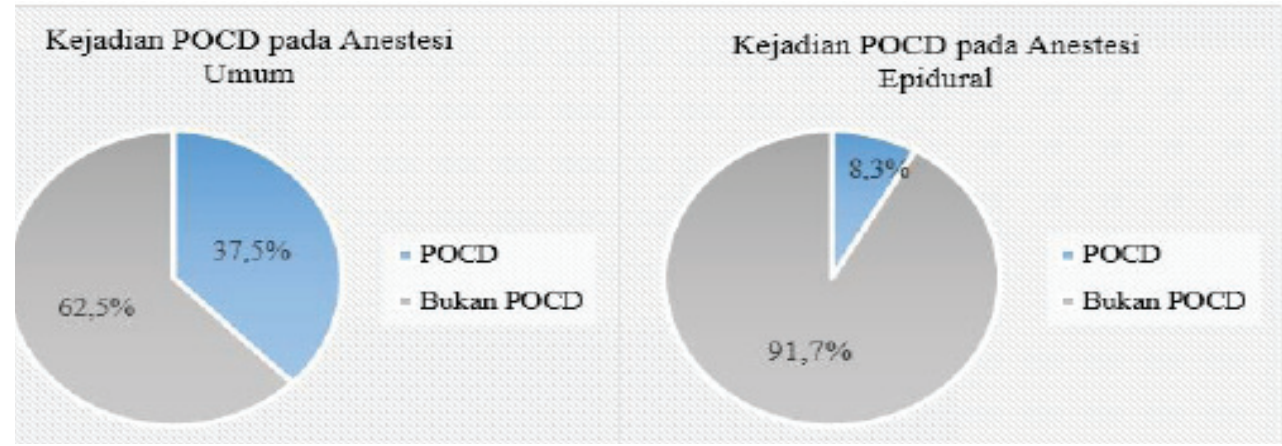

\section{Gambar Proporsi Kejadian POCD}

anestesi sesuai kelompok perlakuan dengan standar prosedur operasional. Pada hari ke-7 pascaoperasi dilakukan penilaian delirium meng-gunakan 4AT test. Pasien yang mengalami delirium dikeluarkan dari penelitian. Pasien yang tidak ditemukan delirium dilanjutkan dengan pemeriksaan tes MMSE. Pemeriksaan MMSE dilakukan oleh dokter yang kompeten dalam pemeriksaan fungsi luhur dan tidak mengetahui perlakuan yang diberikan kepada subjek.

Uji statistik penelitian ini menggunakan uji-t atau uji mann whitney pada data dasar pasien dan data hemodinamik. Sedangkan untuk menilai perbadingan proporsi kejadian POCD pada kedua kelolmpok menggunakan uji chi-square. Data hasil penelitian dicatat dan diolah menggunakan program statistical product and service solution (SPSS) versi 24.0 for windows.

\section{Hasil}

Karakteristik subjek penelitian berdasarkan usia, pendidikan, indeks massa tubuh, dan status fisik ASA antara kelompok GA dan kelompok EA tidak terdapat perbedaan signifikan ( $p>0,05$; Tabel 1).

Lama rata-rata tindakan operasi, lama ratarata lama tindakan anestesi tekanan rerata arteri, dan saturasi oksigen (SpO2) selama operasi tidak didapatkan perbedaan signifikan antara kedua kelompok ( $p>0,05$; Tabel 2).

Penilaian MMSE padaharike-7 pascaoperasi terhadap masing-masing kelompokdidapatkan 9 orang dari kelompok GA mengalami POCD, sedangkan pada kelompok EA terdapat 2 orang yang mengalami POCD. Pada kelompok GA mempunyai proporsi kejadian POCD lebih banyak yaitu $37.5 \%$, sedangkan kelompok EA mengalami POCD sebanyak 8.3\% (Gambar 1).

Hasil uji statistik menunjukkan proporsi kejadian POCD kelompok GA lebih tinggi dan bermakana signifikan dibanding dengan kelompok EA ( $p<0,05$; Tabel 3).

\section{Pembahasan}

Kejadian POCD harus menjadi perhatian ahli anestesi terutama pada pasien yang

Tabel 3 Proporsi Kejadian POCD

\begin{tabular}{lccccc}
\hline & \multicolumn{2}{c}{ Tindakan Anestesi } & \multicolumn{2}{c}{ Total } & Nilai p \\
\cline { 2 - 5 }$(\mathbf{n = 4 8 )}$ & $\begin{array}{c}\text { Anestesi Umum } \\
(\mathbf{n = 2 4 )}\end{array}$ & $\begin{array}{c}\text { Anestesi Epidural } \\
(\mathbf{n = 2 4})\end{array}$ & 2 & 11 & $0,016^{*}$ \\
\hline Subjek yang mengalami POCD & 9 & 22 & 37 & \\
Subjek yang tidak mengalami POCD & 15 & 22 & & 37
\end{tabular}

Keterangan: Data nominal kategorik nilai p diuji dengan uji chi-square. Tanda* menunjukkan nilai $\mathrm{p}<0,05$ artinya signifkan atau bermakna secara statistik. 
mempunyai risiko tinggi mengalaminya. Pemilihan teknik anestesi yang tepat diperlukan untuk meminimalkan dampak tindakan anestesi terhadap kejadian POCD. Hasil penelitian ini menunjukkan proporsi kejadian POCD pada kelompok GA lebih banyak ditemukan dan bermakna secara statistik dibanding dengan EA.

Karakteristik subjek berdasarkan usia, pendidikan, indeks massa tubuh, dan status ASA antara kedua kelompok tidak berbeda bermakna $(p>0,05)$ sehingga kedua kelompok dianggap homogen dan layak dibandingkan. Faktor usia dan pendidikan berperan penting dalam pembentukan cadangan kognitif seseorang. Seseorang dengan cadangan kognitif tinggi dapat melakukan penyesuaian terhadap kerusakan otak tanpa menimbulkan gangguan kognitif. Obesitas meningkatan risiko kejadian POCD melalui perubahan respon inflamasi dan imun terhadap stres operasi. Pasien yang obesitas cenderung memiliki respons inflamasi berlebihan yang berpotensi menyebabkan kerusakan neuron pada sistem saraf pusat dan menimbulkan POCD. Status ASA menggambarkan komorbid yang terdapat pada subjek penelitian. Kelainan sistemik yang berat akan menurunkan kemampuan neuron dalam menghadapi paparan stres operasi dan anestesi sehingga menimbulkan penurunan kognitif pascaoperasi. ${ }^{2,3,7}$

Selama tindakan operasi hemodinamik pasien dimonitor agar tidak menjadi faktor perancu kejadian POCD. Lama operasi, lama anestesi, tekanan arteri rerata, dan SpO2 antara kedua kelompok tidak berbeda bermakna $(p>0.05)$. Semakin lama tindakan operasi belangsung akan meningkatkan paparan obat anestesi dan stres operasi. Kerusakan neuron akibat toksisitas obat anestesi dan stres operasi semakin meningkatkan kejadian POCD. Selama tindakan operasi tidak terdapat kejadian syok dan desaturasi yang dapat merupakan perancu kejadian POCD. Kondisi syok dan desaturasi akan menurunkan pasokan oksigen ke otak dan berpotensi menyebabkan kerusakan neuron yang menimbulkan gangguan kognitif. $1,2,8$

Sampai saat ini patofisiologi POCD belum sepenuhnya diketehui. Salah satu yang diduga sebagai penyebab POCD adalah interaksi antara agen anestesi terhadap sel neuron di otak dan menimbulkan proses patologis seperti pada penyakit Alzheimer. Secara histologis kerusakan neuron ini ditandai adanya kerutan pada neurofibrill intraneuronal dan pembentukan plak amiloid ekstraselular yang merupakan penanda kerusakan neuron. Obat anestesi terutama agen inhalasi diduga menyebabkan perubahan patologis ini dan menyebabkan kerusakan neuron berupa hilangnya sinapsis antarneuron terutama pada neuron kolinergik di daerah forebrain basal. Sistem kolinergik sentral tersebut berperan penting dalam pembentukan dan pengaturan kesadaran, pembelajaran dan ingatan. Proses patologis pada sistem ini akan menimbulkan manifestasi defisit kognitif yang diperkirakan sebagai salah satu hipotesis terjadinya POCD. ${ }^{5,6,9}$

Semua gas anestesi mempunyai pengaruh terhadap kerusakan neuron yang mirip seperti yang terjadi pada penyakit Alzheimer. Penelitian pada tikus yang terpapar sevofluran 2.1\% selama enam jam menunjukkan peningkatan aktivasi caspase-3 (penanda apoptosis) di otak. Peningkatan kadar APP dan peningkatan kadar peptida $A b$ ketika konsentrasi sevofluran menjadi 3\%. Walaupun belum dapat dipastikan relevansi dengan kejadian pada manusia, namun bukti perubahan biologis in vitro ini memberikan informasi tentang mekanisme agen anestesi umum dalam menyebabkan disfungsi kognitif pascaoperasi. Penelitian pada model tikus didapatkan bahwa isofluran dan sevofluran dapat meningkatkan permeabilitas sawar otak melaui perubahan sel endotel vaskular. Perubahan ini lebih jelas terjadi pada model hewan usia tua yang memungkinkan masuknya sitokin dan mediator proinflamasi masuk ke dalam otak. ${ }^{9-12}$

Usia sebagai faktor risiko yang konsisten pada setiap penelitian terhadap kejadian POCD. Kerusakan neuron pada pasien usia tua cendrung menimbulkan manifestasi berupa gangguan kognitif. Penelitian yang dilakukan pada pasien rawat jalan lebih tinggi pada pasien dengan anestesi umum dibandingkan 
dengan anestesi lokal. Fungsi kognitif operasi ortopedi anestesi regional (subarachnoid atau epidural) pada pasien usia lanjut lebih baik dibandingkan dengan anestesi umum. Hasil penelitian ini juga menunjukkan bahwa kejadian POCD pada pasien usia lanjut lebih tinggi secara signifikan pada anestesi umum dibandingkan dengan anestesi epidural. ${ }^{2,3,13}$

Penyebaran obat anestesi pada tindakan anestesi regional terbatas pada level yang relatif tetap di sumsum tulang belakang dan perpindahan obat ke sistem neuron di otak sulit terjadi. Penelitian sebelumnya menemukan fakta menarik bahwa anestesi spinal ternyata dapat mendepresi aktivitas korteks melalui penghambatan aktivitas aferen akibat blok anestesi lokal. Mekanisme penghambatan aktifitas aferen ini kemungkinan juga terjadi pada anestesi epidural. Penelitian lain menyebutkan bahwa ascending reticular activating system (ARAS) membutuhkan input rangsangan sensori agar dapat terus menjaga tingkat kesadaran seseorang. Hal ini yang menjelaskan anestesi epidural dapat menimbulkan efek sedasi akibat penyebaran obat ke ruang subdural. ${ }^{14-16}$

Penelitian pada hewan menemukan anestesi regional ternyata dapat menghambat transmisi somatosensori pada jaras reticulothalamo-cortical. Efek ini dominan terlihat pada model hewan tua dan mekanisme ini secara tidak langsung dapat juga terjadi pada manusia. Penelitian lain juga menemukan keterlibatan sistem somatosensori ascenden dalam anestesi spinal dan epidural yang dapat memengaruhi kesadaran. Lidokain yang disuntikkan ke dalam ruang epidural akan menginduksi efek sedasi, sedangkan lidokain intravena tidak. Penghambatan korteks yang ditimbulkan oleh anestesi epidural disebabkan oleh blok anestesi itu sendiri bukan efek anestesi lokal secara langsung di otak. ${ }^{17,18}$

Blok neuraxial juga mengurangi kebutuhan obat sedasi dan konsentrasi sevofuran melalui penghambatan somatosensori ke jaras reticulo-thalamo-kortikal. Penghambatan pada jaras ini dapat terlihat pada penurunan aktivitas gelombang elctroecephalografy (EEG) di korteks. Saat dilakukan stimulasi pada midbrain reticular formation (MRF) gelombang EEG kembali pada frekuensi dan amplitudenya. Aktivasi kortikal dengan stimulasi MRF yang dapat mengurangi kebutuhan obat anestesi. Kedua mekanisme yang berbeda ini diperkirakan sebagai mekanisme anestesi epidural memengaruhi fungsi korteks. Pusat pengaturan rangsangan pada forebrain ada di thalamus yang memengaruhi aktivitas jaringan saraf dan terlibat dalam fungsi kognitif. Lesi pada thalamus dan obat-obatan yang menghambat aktivitas saraf menyebabkan perubahan memori. Inti talamik bagian sentral meliputi inti di garis tengah, intralaminar dan daerah paralaminar mengandung matriks neuron padat, berfungsi menyinkronkan aktivitas dalam jaringan saraf serebral yang mendasari fungsi kognitif. ${ }^{17,19,20}$

Kejadian POCD pada tindakan epidural pada penelitian ini kemungkinan bisa disebabkan oleh mekanisme yang diterangkan di atas. Penghambatan rangsang somatosensori ke jaras menuju thalamus oleh tindakan epidural kemungkinan dapat memengaruhi kognitif pascaoperasi. Selain itu, faktor risiko yang tidak bisa dimodifikasi pada subjek penelitian yaitu usia lanjut juga memengaruhi kejadian POCD. Tingkat stress operasi menyebabkan pelepasan mediator inflamasi dan sitokin yang menyebabkan kerusakan pada sel neuron yang memengaruhi kejadian POCD pada fase akut ini. ${ }^{1,2,14-20}$

Keterbatasan pada penelitian ini adalah waktu penilaian kejadian POCD hanya dilakukan pada fase akut yaitu pada 7 hari pascaoperasi. Peneliti tidak membandingkan kejadian POCD pada fase lanjut yaitu tiga bulan dan satu tahun pascaoperasi. Kejadian POCD pada fase akut dapat berlanjut dan menetap sebagai gangguan kognitif pada pasien, tetapi dapat juga hilang seiring dengan perjalanan waktu. Penelitian ini tidak dapat menggambarkan kelanjutan pasien yang mengalami POCD pada masa berikutnya. Penelitian ini juga tidak bisa menghilangkan faktor stres operasi yang juga berpengaruh terhadap kejadian POCD. Pada penelitian berikutnya dapat dilakukan penelitian yang membandingkan kejadian POCD pada berbagai 
jenis operasi dengan anestesi yang sama atau kombinasi antara GA dan EA.

\section{Simpulan}

Kejadian postoperative cognitive dysfunction fase akut pasca joint arthroplasty pada pasien usia lanjut dengan GA lebih banyak dibandingkan dengan EA.

\section{Daftar Pustaka}

1. Urits I, Orhurhu V, Jones M, Hoyt D, Seats A, Viswanath 0. Current perspectives on postoperative cognitive dysfunction in the ageing population. Turk J Anaesthesiol Reanim. 2019;47(6):439-47.

2. Monk TG, Weldon BC, Garvan CW, Dede DE, van der Aa MT, Heilman KM, dkk. Predictors of cognitive dysfunction after major noncardiac surgery. Anesthesiology. 2008;108(1):18-30.

3. Feinkohl I, Winterer G, Speis CD, Pischon, T. Cognitive reserve and the risk of postoperative cognitive dysfunction. Dtsch Arztebl Int. 2017;114(7):110-7.

4. da Silva RR, Santos AA, de Sampaio Carvalho Júnior J, Matos MA. Quality of life after total knee arthroplasty: systematic review. Rev Bras Ortop. 2014;49(5):520-7.

5. Shi Hui-Jian, Xue Xin-Hong, Wang YueLan, Zhang Wen-Sheng, Wang Zi-Shen, Yu Ai-Lan. Effects of different anesthesia methods on cognitive dysfunction after hip replacement operation in elder patients. Int J Clin Exp Med. 2015; 8(3): 3883-8.

6. Le Freche H, Brouillette J, FernandezGomez Fj, Patin P, Caillierez R, Zommer $\mathrm{N}$, dkk. Tau Phosphorylation and Sevoflurane Anesthesia: An Association to Postoperative Cognitive Impairment. Anesthesiology: J Am Soc Anesthesiol. 2012;116(4):779-87.

7. Feinkohl I, Winterer G, Pischon T. Obesity and post-operative cognitive dysfunction: a systematic review and meta-analysis. Diabetes Metab Res Rev. 2016;32(6):64351.

8. Ni C, Xu T, Li N, Tian Y, Han Y, Xue $Q$, dkk. Cerebral oxygen saturation after multiple perioperative influential factors predicts the occurrence of postoperative cognitive dysfunction. BMC Anesthesiol. 2015;15:156.

9. Le Freche H, Brouillette J, FernandezGomez FJ Patin P, Caillierez R, Zommer $\mathrm{N}$, dkk. Tau Phosphorylation and Sevoflurane Anesthesia: An Association to Postoperative Cognitive Impairment. Anesthesiology. 2012;116(4):779-87.

10. Hadžimešić $M$, Imamović $S$, Uljić $V$, Hodžić M, Iljazagić-Halilović F, Hodžić R. Cognitive function recovery rate in early postoperative period: comparison of propofol, sevoflurane and isoflurane anesthesia. J Health Sci. 2013;3(1):48-54.

11. Zhang B, Tian M, Zhen Y, Yue Y, Sherman J, Zheng $\mathrm{H}$, dkk. The effects of isoflurane and desflurane on cognitive function in humans. Anesth Analg. 2012;114(2):4105.

12. Zhang Y, Shan GJ, Zhang YX, Cao SJ, Zhu SN, Li HJ, dkk. Propofol compared with sevoflurane general anaesthesia is associated with decreased delayed neurocognitive recovery in older adults. $\mathrm{Br}$ J Anaesth. 2018;121(3):595-604.

13. Schraag S, Pradelli L, Alsaleh AJO, Bellone M, Ghetti G, Chung TL, dkk. Propofol vs. inhalational agents to maintain general anaesthesia in ambulatory and in-patient surgery: a systematic review and meta-analysis. BMC Anesthesiol. 2018;18(1):162.

14. Arisaka H, Sakuraba S, Takeda J. Effects of spinal anesthesia on the electroencephalogram in the elderly. Acta Anaesthesiologica Belgica. 2008;59(1):157.

15. Lu CH, Chen JL, Wu CT, Liaw WJ, Yeh $\mathrm{CC}$, Chemg $\mathrm{CH}$, dkk. Effect of epidural neuraxial blockade-dependent sedation on the Ramsay Sedation Scale and the composite auditory evoked potentials index in surgical intensive care patients. J Formos Med Assoc. 2010;109(8):589-95.

16. Dardis C, Lawlor D, Schusse CM. Transient coma due to epidural anesthesia: the role 
of loss of sensory input. Am J Case Rep. 2015;16:893-8.

17. Carstens E, Antognini J. Anesthetic effects on the thalamus, reticular formation and related systems. Thalamus Relat Syst. 2005;3:1-7.

18. Hamp T, Krammel M, Weber U, Schmid R, Graf A, Plochl W. The effect of a bolus dose of intravenous lidocaine on the minimum alveolar concentration of sevoflurane: a prospective, randomized, double-blinded, placebo-controlled trial. Anesth Analg.
2013;117(2):323-8.

19. Jeenger L, Jeenger J, Dulara SC, Joshi A. A comparative study of postoperative cognitive dysfunction in elderly patients undergoing hip surgery after general anaesthesia and combined spinal and epidural anaesthesia. Indian J Clin Anaesth 2016;3:362.

20. Mair RG, Onos KD, Hembrook JR. Cognitive activation by central thalamic stimulation: the yerkes-dodson law revisited. Dose Response. 2011;9:313-31. 